\title{
INTERNATIONAL EXPERIENCE IN ORGANIZATION OF TEACHING PRACTICE IN TEACHER TRAINING AND SOME RECOMMENDATIONS
}

\author{
Her Chongmouayang ${ }^{1,+}$, \\ Nghi Van Bui ${ }^{2}$
}

\section{Article History}

Received: July 11, 2020

Accepted: August 28, 2020

Published: September 30, 2020

\section{Keywords}

Pre-service teacher, mathematics teacher, teacher training

\author{
${ }^{1}$ Khangkhay Teacher Training College, Lao People's Democratic Republic; \\ ${ }^{2}$ Hanoi National University of Education, Vietnam \\ ${ }^{+}$Corresponding author $\bullet$ Email: heryang50@ gmail.com
}

\section{INTRODUCTION}

Education is dynamic and subject to change; as a result, teachers are required to be able (and willing) to adjust their teaching to overcome new challenges from their working environment and the society in general. Nowadays teachers are expected to meet new demands, ranging from contributing to social welfare in an increasingly more individual-oriented society; keeping pace with technological developments, realizing educational innovations and fulfilling tasks at school organizational level (Beijaard, 1992).

Teacher education (teacher training in pedagogical universities) cannot provide expert teachers, but it must be possible to contribute to the development of personalities who are able and willing to become expert teachers.

The paradigm approach sees good or adequate teaching as the expression of a group of three strategies: (1) mastering specific teaching 'skills' which can be identified ('training' paradigm), (2) being able to critically reflect on personal and situational teaching aspects and (3) teaching based on experience through reflection-in-action (Tillema, H.H., 1991).

There are some research reports on widespread dissatisfaction with the quality of pre-service teacher training due to a host of factors, including a dichotomy between theory and practice, excessive fragmentation of knowledge and a tenuous tie between teacher-training institutions and the schools where teachers exercise their profession (Leonardo López-Neira et al. t., 2020). There is a gap between knowing about teaching and practising teaching (Ball and Forzani 2010); that is, what teachers do in the teaching process may be inconsistent with what they learned at pedagogical universities. Therefore, the enhancement of teaching training activities with guidance may be a way for teacher preparation programs to bridge such a gap between knowing and doing.

This study aims to provide recommendations for innovation in teacher training in Laos, with a focus on developing the pre-service teachers' teaching capacity (in the case of pre-service mathematics teachers).

\section{LITERATURE REVIEW}

The implementation of the training module on classroom interaction strategies based on complementing traditional classes with the use of an interactive digital game significantly improved the level of recognition, capacity for analysis and coherent design of classroom verbal interactions in pre-service student teachers ((Leonardo LópezNeira et al. t., 2020).

For many educators around the world, research-based lessons are the key to analyzing and understanding what actually happens in the classroom. These lessons require professional knowledge to face the complexity of classroom practice (Hobson et al., 2009; Loughran, 2016). 
The paper provides empirical insights into the way lesson study reinforced the pre-service teachers' classroom management and lesson planning skills (Maria Laura Angelini, Neus Álvarez, 2017).

The ability to do or participate in research can be seen as an aspect of a teacher or teaching competence because it: (1) stimulates a teacher's confidence and communicative skills (also with relevant academics), (2) supports a teacher's flexibility in terms of an increased tolerance with respect to ambiguity and uncertainty, (3) stimulates intellectual competencies like perception, understanding and judgement and (4) prevents a teacher from not only being occupied with means but also with outcomes. It is also worth studying the pre-service mathematics teacher (PMT) implementation study that undertakes pedagogical practice, such as the study of teaching, not just actual implementation. That is, through teaching practice, PMT needs to study the student's learning process, review the application of reasoning in teaching, and re-study teaching contents such as program knowledge, academic knowledge and pedagogical transformation knowledge as well.

It is essential to place concrete student-teacher' learning in the context of personal development in relationship with being a teacher according to general and context-specific demands (macro-genetic planning of education) (D. Beijaard, 1994). This highlights the appreciation of the role of vocational skills training, which is placed in practical career contexts.

The study by Beijaard, D. (1992) makes a very detailed recommendation on teacher training as follows: The operationalization of the teacher education curriculum preferably occurs on the basis of special didactics. Four aspects of this didactics will be described below.

i) Educational and didactic knowledge should be integrated into student teachers' existing knowledge, attitudes and beliefs. This implies that teacher educators cannot transmit knowledge in the hope that student teachers transfer this knowledge to their own teaching in schools. They can offer knowledge or create learning possibilities, but learning is first of all the activity of the learner.

ii) In teacher education, the exchange between objective and subjective theory and learning to teach can be combined by addressing a student teacher's 'zone of proximal development' (that is to say, the level of potential development, to be distinguished from the level of actual development, and which can be reached through problemsolving under guidance or in collaboration with more capable peers). From this point of view, a teacher educator must start from orientations that guide a student teacher's actions and be aware that these orientations are the result of experiences and reflection processes.

iii) It is essential that teacher education anticipates developments in education. Student teachers should, for example, get familiar with problem-based learning when this type of learning frequently takes place in schools.

iv) It is essential that student teachers learn as a researcher on the aspects of their teaching practice. Doing research stimulates reflection, and being a reflective practitioner is nowadays seen as a relevant characteristic of good or adequate teaching.

The remarkable study by Wubbels (1992) gives some of the following recommendations for new graduates. For becoming a professional teacher, Wubbels (1992) proposes the following structure for 'in-service' teacher education:

1. a period of two years after pre-service education, in which the teacher is called a junior teacher who teaches a limited number of lessons under the supervision of an experienced colleague; in this period the teacher also participates in schooling activities (for example with regard to curriculum development, tests and research);

2. a period of several years in which the teacher does everything a teacher normally does and in which perspectives are developed for further professionalization;

3. a remaining period characterized by differentiation of tasks among teachers based on additional education (for example, with regard to didactics, middle-management and guiding for students).

Of course, in many countries, such an implementation is not quite feasible. For Laos, this can also be taken into account in the process of teacher training in pedagogical schools. For example, for 3rd and 4th-year students, it is possible to do activities 1 and 2 as suggested by Wobbles.

Research by Jing Cheng (2017) shows that micro-teaching and the support of high school teachers with experience in teacher training are very meaningful and effective. This research indicates that micro-teaching guided by expert secondary mathematics teachers can help pre-service teachers attend to precision in their classroom teaching, yet some lack of precision in performance was still observed in the pre-service teachers' lessons. The guidance and the exemplary lessons of expert teachers played an important role in changing the pre-service teachers' performance (Jing Cheng, 2017). Research has shown many deficiencies in language, expression, teaching 
organization, student interaction, or teaching skills (such as drawing pictures, answering questions or not responding to errors of students) of the future math teacher (PMT). Furthermore, the fact that they can work with expert teachers helps them to learn and evolve, rather than working with only peer students. Since then, the study recommends that teacher training in the form of micro-teaching also needs to be changed in the direction of practices, not just the interaction between pre-service teachers (pre-teachers). There is also a need for the role of expert teachers in class. This comment is a meaningful recommendation for the training of math teachers in particular, teacher training, in general, owing to the changes in training processes and methods.

A qualified mathematics teacher needs to solve math problems correctly, express it normatively and reason it rigorously; most of the expert mathematics teachers pay much attention to precision when guiding the teaching practice and providing the exemplary lessons. From an Oriental perspective, expert teachers also play a role as teacher educators (Yang 2013). For example, a new teacher is usually assigned to an experienced teacher as his/her mentor. The mentor will help the pre-teacher in a comprehensive way from lesson preparation to assignment correction. A policy implication is that exemplary teachers' support is significant for teacher preparation programs, in order to supplement the training and elevate it to a relevant high level (Wang and $\mathrm{Gu} 2007$ ).

Teaching consists of personal, contextual, professional, moral and emotional dimensions, which is primarily expressed in practice. In this practice, teaching can be characterized by (Lowyck, 1984): + multidimensionality: different students, divergent reactions and activities and; + interruptions; + simultaneity: many occurrences at the same time; + immediacy: little time to think for teachers; + unpredictability: it is impossible to predict what will occur with certainty so it is challenging to decide unequivocally; + dependency on time: activities, decisions or events have consequences for following situations.

In general, a teacher's knowledge base encompasses knowledge of subject-matter, subject-matter related academic or didactic knowledge and knowledge of parts of educational theories.

The study on how to train science teachers in South African by Wiets B. et al. (2020) gives a recommendation on organizing a lesson study for pre-service teachers during the training process. In this study, the generation of knowledge was inseparably associated with the collaborative practices and interaction that existed between the team of pre-service teachers. The lesson study approach allows an engaging space characterized by values of trust, respect, support, and empathy for each other. The collaborative practices that form part of the team dynamics challenge the conventional belief that teacher educators are the ones in power who poses absolute knowledge. This approach symbolizes the collective role that the team of pre-service teachers play in the structuring of lessons.

Another approach, related to the exploitation and use of information technology in teacher training as well as contributing to the development of the capacity to use information technology in teaching Mathematics presented by Monika Dockendorff \& Horacio Solar (2017) shows that incorporating an ICT into the mathematics education courses contributes not only to efficient use of technology for mathematics teaching and to promoting a more dialogical teacher role in the classroom, but also to the modification of conceptions about mathematics and its education. By way of using ICT (GeoGebra), pre-service teachers reconfigure his mathematics teaching conceptions from different dimensions. Similarly, Ilhan Karatas (2014) offers empirical evidence that pre-service mathematics teachers' experiences in computer-based mathematics courses played a significant role in this change. Teacher education programs should consider this learning method for pre-service teachers. Learning and teaching experiences with computers are significant factors in changing pre-service teachers' beliefs. This finding is also important for implementing reforms in mathematics education.

Some studies in Vietnam have suggested a number of techniques or measures to develop teaching capacity for mathematics pre-service teachers. Le D.C (2017) shows that organizing seminars in teaching Mathematics teaching method for students in Primary Education would help develop teaching capacity for students. Nguyen Duong Hoang (2008) proposes a number of solutions to organize the training of teaching skills: Building and developing a program of Math teaching method, integrating skill training into each knowledge circuit of the method of Mathematics teaching, performing regular pedagogical activities, installing and exploiting effective teaching facilities and strengthening skills in using information technology for students.

\section{RESEARCH METHODS AND RESULTS}

\subsection{Research methods}

This study is conducted using document analysis method. To propose some suggestions for modifying or changing the teacher training program, the documents included in the analysis include the two following categories: 
+ Type 1: Studies on teacher training in general, and math teacher training in particular, with the keywords "teaching practice", "pre-service teacher".

+ Type 2: Regulating documents on the teacher training program in the Lao People's Democratic Republic, the math teacher training curriculum in some pedagogical colleges in Laos.

\subsection{Research context}

In Laos, prospective mathematics teachers of secondary schools receive four years of college education in mathematics education programs. For example, according to the Math Teacher Training Program in Laos, the "Math Teaching Methods" course is worth four credits (studying in two semesters in the third year) and the course "Career Experience." Three credits (studying in 3 semesters: one in the second year and two in the third year), equal to $2.5 \%$ of the entire program duration. The contents of the "Math Teaching Methods" course include the basic theories, which are the "student-centred, teacher-centred" method, Bloom's Taxonomy's cognitive theory, and basic elements of the lesson plan. The instructors of this course only instruct the teaching method according to their own experiences for students, without an outline, lecture content; then let students practice choosing their own topics and personal lectures, only a few students were allowed to go to the board to practice due to the limit of time. Furthermore, there is currently no adequate cooperation with high schools in teacher training; the application of information technology in teacher training to help them use mathematics software in teaching is minimal.

\subsection{Results}

From the above analysis, we suggest some recommendations for reforming the teacher training program in the Lao People's Democratic Republic (Mathematics teacher) as follows:

First, the role of Mathematical Content Knowledge in teacher training should be highly appreciated as an essential foundation for appropriate and competent Mathematics teaching as well as providing opportunities for career development, including teaching skills.

Secondly, a greater emphasis needs to be placed on equipping knowledge related to student learning, such as the ability to learn math, math learning habits, interest in math and educational problems related to those contents in teaching. This activity helps prepare pre-service mathematics teacher for their future career in the aim of a better performance in the process of teaching Mathematics after graduation.

Thirdly, it is advisable to increase further the time for students to organize teaching practice. The teaching practice should focus on and meet some requirements, noting the following: + Teaching practices in lecture halls play an essential role, but teaching practice activity must be conducted at high schools; + It is necessary to have the coordination and support of experienced teachers (not any teachers) in the teaching practice of future math teachers at the school; + Teachers need to be assigned the suitable and increasingly-challenging tasks as real teachers to practice, experience, comment, adjust and train; + Time for teaching practice in high schools should be increased. Studies do not specify how much is appropriate and sufficient, but the author suggests that the practise time should be equivalent to that for learning the general educational theories and mathematical educational theories. It means increasing the amount of time spent on the educational courses (Mathematics and some educational science ones) as well as considering rearranging the advanced math content appropriately; + Micro-teaching, lesson study are useful techniques that should be used in the organization process for prospective students to practice pedagogical skills. These contents will help them develop analytical competencies in teaching, program analysis, and practice teaching skills.

Fourth, it is necessary to exploit information technology in organizing pedagogical practice for teachers in general and future math teachers in particular. Thus, it is required to address two issues: application of information technology in teaching organization (teaching software such as PowerPoint) and application of mathematical applications (such as GeoGebra). Regarding mathematical applications, it is necessary to approach teaching organization, rather than just using it to solve math exercises.

Fifth, it is believed that lecturers in teacher training schools also need to experience the teaching process in schools because, in coordination with high school teachers in pedagogical practice training, the innovative teaching experience in schools could help them develop better and more effective teaching and training plans and develop teaching competencies for the pre-service teachers.

\section{DISCUSSION AND CONCLUSION}

Developing teaching competencies for future teachers has been increasingly concerning the Ministry of Education and Sports of the Lao People's Democratic Republic. This topic has long appealed to many researchers in 
the world, which results in the introduction of various techniques, proposals, and requirements for innovation in the training process to develop teaching capacities for future teachers.

The recommendations we propose based on the analysis of previous studies hopefully would contribute to preparing future teachers for their initial post-graduation stages of practising pedagogy at school. These recommendations also aim to help pedagogic schools to innovate the process and organization of training professional skills for future teachers. More specifically, it is necessary to have an appropriate investment in time and the approach to develop professional skills for teacher trainees.

\section{REFERENCES}

Ball, D. L., \& Forzani, F. M. (2010). Teaching skillful teaching. Educational Leadership, 68(4), 40-45.

Beijaard, D. (1992). Docent nieuwe stijl: ideaal of werkelijkheid? Landbouwuniversiteit Wageningen: Vakgroep Agrarische Onderwijskunde.

D. Beijaard (1994). Teacher competence, everyday teaching practice and professionalization. European Journal of Agricultural Education and Extension, 1(2), 65-80. doi:10.1080/13892249485300161

Hobson, A. J., Ashby, P., Malderez, A., \& Tomlinson, P. D. (2009). Mentoring beginning teachers: What we know and what we don't. Teaching and Teacher Education, 25, 207-216.

Ilhan Karatas (2014). Changing pre-service mathematics teachers' beliefs about using computers for teaching and learning mathematics: the effect of three different models. European Journal of Teacher Education, 37(3), 390405. http://dx.doi.org/10.1080/02619768.2013.870993

Jing Cheng (2017). Learning to attend to precision: the impact of micro-teaching guided by expert secondary mathematics teachers on pre-service teachers' teaching practice. ZDM Mathematics Education, 49, 279-289. doi:10.1007/s11858-017-0839-7

Le Duy Cuong (2017). Seminar Organization in teaching the subject of Math teaching methods for primary teacher students. Doctoral thesis, Hanoi National University of Education, Vietnam.

Leonardo López-Neira, Christian Labbé \& Marco Villalta (2020). Digital game for the development of classroom verbal interaction strategies: enhanced pre-service teacher training model with technology. Culture and Education. doi:10.1080/11356405.2020.1785139

Loughran, J. J., Keast, S., \& Cooper, R. (2016). Pedagogical reasoning in teacher education. In J. J. Loughran, \& M. L. Hamilton (Eds.), International handbook of teacher education, Dordrecht: Springer, 1, 387-422.

Lowyck, J. (1984). Teacher thinking and teacher routines: a bifurcation?. In: R. Halkes and J.K. Olson (eds.), Teacher thinking: a new perspective on persisting problems in education. Lisse, Swets \& Zeitlinger, 7-18.

Maria Laura Angelini, Neus Álvarez (2017). Spreading lesson study in pre-service teacher instruction. International Journal for Lesson \& Learning Studies, 7(1), 23-36. doi:10.1108/IJLLS-03-2017-0016

Monika Dockendorff \& Horacio Solar (2017). ICT integration in mathematics initial teacher training and its impact on visualization: the case of GeoGebra. International Journal of Mathematical Education in Science and Technology, 49(1), 66-84. doi:10.1080/0020739X.2017.1341060

Nguyen Duong Hoang (2008). Organizing teaching activities in Mathematics Teaching Methodology course to strengthen training teaching skills for students. Doctoral thesis, Vinh University, Vietnam.

Tillema, H. H. (1991). Kwaliteit van de lerarenopleiding. Tijdschrift voor Hoger Onderwijs, 9(1), 19-30.

Wang. J. \& Gu. L. (2007). School-based research and professional learning with the aim at improving classroom practice. Retrieved from http://www.ied.edu.hk/wals/conference07/resources/wals07/3_28112007_china.pdf

Wiets B. et al. (2020). Supporting Natural Science Pre-Service Teachers during Work-Integrated Learning: A Case of a Lesson Study Approach. International Journal of Learning, Teaching and Educational Research, 19(10), 60-76. doi:10.26803/ijlter.19.10.4

Wubbels, Th. (1992). Leraren tellen. Rede uitgesproken bij de aanvaarding van het ambt van bijzonder hoogleraar op het vakgebied 'Leraarsgedrag als factor in leeromgevingen'. R.U. Utrecht.

Yang, X. (2013). Conception and characteristics of expert mathematics teachers in China. Wiesbaden: Springer. 